\title{
EFFECT OF CAPTOPRIL ON GENTAMICIN INDUCED NEPHROTOXICITY IN RATS
}

\author{
RAHMAN MH ${ }^{1}$, HOSSAIN MZ ${ }^{2}$, RAHMAN MA ${ }^{3}$, KHAN MI $^{4}$
}

\begin{abstract}
The present study was performed to investigate the nephroprotective effects of captopril in experimentally induced nephrotoxicity in rats. To demonstrate this effect, serum level of creatinine and blood urea nitrogen(BUN) was chosen. Histological examination of kidney was also performed. For the purpose of the study 35 long Ivan rats were taken divided into five

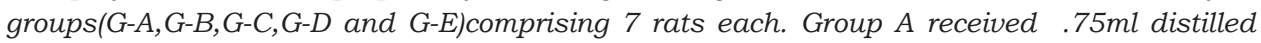
water subcutaneously in addition to normal diet, and served as control. Group B was treated with gentamicin $125 \mathrm{mg} / \mathrm{kg}$ subcutaneously for 9 days and served as experimental group. Group $C, D$ and $E$ were designed to demonstrate the nephroprotective effect. In this part of experiment, group $C$ was treated with only gentamicin $125 \mathrm{mg} / \mathrm{kg}$ subcutaneously for 9 days and served as control. Group D and group E were treated with captopril $9 \mathrm{mg} / \mathrm{kg}$ and $11 \mathrm{mg} / \mathrm{kg}$ orally respectively, in addition to gentamicin. Mean serum creatinine and BUN level raised highly significantly in group B in comparison to group A after 9 days treatment with gentamicin. Histological findings showed a number of necrosed proximal convoluted tubules in group $B$ whereas normal architecture is preserved in group A. Co administration of captopril prevented significantly gentamicin induced increase serum creatinine and BUN. Though histological findings did not correlate with biochemical findings and there are significant numbers of necrosed proximal convoluted tubules. From the result and observations of the present study and their comparison with the works of other researchers, it may be concluded that captopril is beneficial in protecting gentamicin induced nephropathy. Thus, it could be useful in nephrotoxic conditions, such as hypertension with acute glomerulonephritis, acute renal failure and chronic renal failure. But before establishing captopril as a therapeutically effective nephroprotective agent further studies should be carried out to determine the nephroprotective effect and its cellular mechanism as well as any clinical trial for suitability of using in man.
\end{abstract}

Key Words: Captopril, Gentamicin Induced Nephrotoxicity.

J Dhaka Med Coll. 2009; 18(1) : 3-7

\section{Introduction}

Approximately $8 \%$ to $26 \%$ of patients who receive an amino glycoside for several days will develop mild renal impairment that is almost always reversible. The toxicity results from accumulation and retention of aminoglycosides in the proximal tubular cell. The initial manifestation of damage at this site is enzyme leakage of the renal tubular brush border. After several days, there is a defect in renal concentrating ability, mild proteinuria and the appearance of hyaline and granular casts. The glomerular filtration rate is reduced after several additional days. ${ }^{1}$
The blood pressure in many patients with chronic renal failure, despite multiple drug combination, is difficult to control. With the introduction of captopril, an angiotensin converting enzyme inhibitor, control of blood pressure in patients with refractory hypertension may be possible. ${ }^{2}$

Gnetamicin, an effective and widely used amino glycoside antibiotic, is known to be potentially nephrotoxic. Administration of gentamicin to healthy Fischer rats regularly and rapidly produced characteristic dose related functional and anatomical renal changes.

1. Assistant Professor, Department of Pharmacology, Dhaka Medical College, Dhaka.

2. Assistant Professor, Department of Medicine, Dhaka Medical College and Hospital, Dhaka.

3. Lecturer, Department of Microbiology, Dhaka Medical College, Dhaka.

4. Professor and Head, Department of Pharmacology, Dhaka Medical College, Dhaka.

Correspondence : Dr. Md Hasanur Rahman 
Gentamicin at low dose resulted in formation of numerous lysosomal cytosegresomes, many of which contained prominent myeloid bodies, which occurred most commonly in proximal convoluted tubular cells and to a lesser extent in glomerular and distal tubular epithelium. ${ }^{3}$

Gentamicin, at higher doses, produces functional impairment consisted of polyuria, increased blood urea nitrogen and decreased urea clearance. Massive tubular necrosis and oliguria also occurred. Prominent myeloid bodies in lysosomal cytosegresomes of renal tubular epithelium appear to be a sensitive indicator of gentamicin toxicity. ${ }^{3}$

Clinical trail of gentamicin showed that about $30 \%$ of the patients who had used the aminoglycoside for more than 7 days may develop some signs of nephrotoxicity ${ }^{4}$ (Mathew, 1992). A report by Zager and Sharma (1983), (cited by Bagum ${ }^{5}$ ) states that between $3 \%$ and $18 \%$ patient would show rise in serum creatinine concentration following treatment with gentamicin. About $8 \%$ to $11 \%$ of patients receiving amino glycosides develop mild renal impairment ${ }^{6}$. A report by Wilfert et al. ${ }^{7}$ states that out of 77 patients who received genamicin, 71 develop acute renal failure (ARF). In five cases, gentamicin appeared to be the most likely cause of renal insufficiency.

Some patients treated with gentamicin may progress to acute renal failure, and among them, a significant number had received gentamicin before the onset of the syndrome ${ }^{8}$. Walker and $\mathrm{Shah}^{9}$ found that 10 to $15 \%$ all cases of acute renal failure were users of amino glycosides.

Captropril has been reported to prevent renal failure associated with the hypertensive crisis of scleroderma. ${ }^{10,11}$ and is now recommended as the drug of choice for this syndrome. However once the condition has progressed to frank renal failure, the drug in only variably effective $^{12}$ and thus early intervention is important for long lasting success ${ }^{13}$ Some patients have been treated successfully for as long as two years.

With this background information, in this study, attempt has been made to evaluate the nephroprotective role of captopril on experimentally induced nephrotoxicity in rats. Gentamicin has been chosen to induce the nephrotoxicity.

\section{Materials and Methods:}

This experimental study was carried out at the Department of Pharmacology and Therapeutics, Dhaka Medical College (DMC), Dhaka, during the period from July 2007 to June 2008.

A total number of 35 long Evans rats of either sex were used for the present study. The rats were fed normal diet and allowed to drink water ad libitum. The rats were divided into five groups. A, B, C, D, E. Each group consists of seven rats.

\section{Experimental Design:}

Experiment-I:

The Experiments were designed to demonstrate the nephrotoxic effect of gentamicin in normal rats. Nephrotoxicity was induced by the administration of gentamicin at a dose of 125$\mathrm{mg} / \mathrm{kg}$ body weight subcutaneously daily for nine days. The total animals were fourteen. The animals were divided into two groups.

Group A (control): Consist of 7 rats that received normal diet and $0.75 \mathrm{ml}$ of normal saline subcutaneously daily for 9 days and served as control.

Group B (gentamicin treated): Consist of 7 rats and received gentamicin at a dose of $125-\mathrm{mg} /$ $\mathrm{kg}$ body weight subcutaneously daily for 9 days.

On $10^{\text {th }}$ day the rats were sacrificed, blood collected, and kidney was preserved in 10\% formalin for histological study.

\section{Experiment-II:}

In experiment-II, nephroprotective effect of captopril an angiotensin converting enzyme inhibitor, was studied in gentamicin induced nephrotoxic rats. Total animals were twentyone. The animals were divided into three groups as follows.

Group C (control): Consist of 7 rats that received normal diet and gentamicin at a dose of $125 \mathrm{mg} /$ $\mathrm{kg}$ body weight subcutaneously daily for 9 days and served as control. 
Group D (Captopril $9 \mathrm{mg} / \mathrm{kg}$ body weight treated group): Consist of 7 rats that received normal diet and gentamicin at a dose of $125-\mathrm{mg} / \mathrm{kg}$ body weight subcutaneously and captopril at a dose of $9 \mathrm{mg} / \mathrm{kg}$ body weight orally daily for 9 days.

Group E (Captopril $11 \mathrm{mg} / \mathrm{kg}$ body weight treated group):

Consist of 7 rats that received normal diet and gentamicin at a dose of $125 \mathrm{mg} / \mathrm{kg}$ body weight subcutaneously and captopril at a dose of 11 $\mathrm{mg} / \mathrm{kg}$ body weight orally daily for 9 days.

On the $10^{\text {th }}$ day the rats were sacrificed, blood was collected and kidney was preserved in 10\% formalin for histological study.

\section{Observation \& Results:}

Effect of Gentamicin on Serum Creatinine and blood urea nitrogen (BUN of rats) in experiment I: The mean $( \pm \mathrm{SE})$ serum creatinine of rats in group A was $0.5529( \pm 0.11) \mathrm{mg} / \mathrm{dl}$ and group B was $2.25( \pm 0.23) \mathrm{mg} / \mathrm{dl}$. The serum creatinine of rats in group $\mathrm{B}$ was increased in comparison to group A which was highly significant $(\mathrm{P}<0.001)$. The mean $( \pm \mathrm{SE})$ blood urea nitrogen (BUN) of rats in group A was $16.14( \pm 0.92) \mathrm{mg} / \mathrm{dl}$ and group B was 116.14( \pm 0.32$) \mathrm{mg} / \mathrm{dl}$. The blood urea nitrogen (BUN) of rats in group B was Increased in comparison to group A which was also highly significant $(\mathrm{P}<0.001)$.

\section{Effect of Gentamicin on proximal convoluted} tubules of rats experiment $I$.

The mean number of necrosed proximal convoluted tubules of rats in group A was 0/ $\mathrm{HPF}$ and group B was $12.85 / \mathrm{HPF}$. The mean number of necrosed convoluted tubules of rats in group B increased in comparison to group A which is highly significant $(\mathrm{P}<0.001)$.

Effect of Captopril on Serum Creatinine of rats in Gentamicin induced nephrotoxic rats in experiment II.

The mean $( \pm \mathrm{SE})$ serum creatinine of rats in group $\mathrm{C}$ was $2.30( \pm 0.31) \mathrm{mg} / \mathrm{dl}$ and group $\mathrm{D}$ was $1.24( \pm 0.7) \mathrm{mg} / \mathrm{dl}$ and group $\mathrm{E}$ was $1.37( \pm 0.11) \mathrm{mg} / \mathrm{d} l \mathrm{respectively}$. The serum creatinine of rats in group D was decreased in comparison to group $\mathrm{C}$ which is very significant $(\mathrm{P}<0.01)$. The serum creatinine of group $\mathrm{E}$ was decreased in comparison to group $\mathrm{C}$ which is significant $(\mathrm{P}<0.05)$.

\section{Table-I}

Effect of Captopril on Serum Creatinine of rats in Gentamicin induced nephrotoxic rats in experiment II.

\begin{tabular}{lcc}
\hline Group of rats & No of rat (n) & $\begin{array}{c}\text { Serum } \\
\text { Creatinine mg/dl } \\
\text { (Mean } \pm \text { SEM) }\end{array}$ \\
\hline C & 7 & $2.30 \pm 0.31$ \\
Control & & $1.24 \pm 0.7^{*}$ \\
D & 7 & \\
Experimental & & $1.37 \pm 0.11^{*}$ \\
E & 7 & \\
Experimental & & \\
\hline
\end{tabular}

Effect of Captopril on blood urea nitrogen (BUN) of rats in Gentamicin induced nephrotoxic rats in experiment II.

The mean $( \pm \mathrm{SE})$ blood urea nitrogen $(\mathrm{BUN})$ of rats in group $\mathrm{C}$ was $117.00( \pm 1.11) \mathrm{mg} / \mathrm{dl}$ and group D was $85.28( \pm 1.14) \mathrm{mg} / \mathrm{dl}$ and group $\mathrm{E}$ was $75.00( \pm .81) \mathrm{mg} / \mathrm{dl}$ respectively. The blood urea nitrogen (BUN) of rats in group D was decreased in comparison to group $\mathrm{C}$, which was highly significant $(\mathrm{P}<0.001)$. The mean blood urea nitrogen of rats in group $\mathrm{E}$ was decreased in comparison to group $\mathrm{C}$, which was very significant $(\mathrm{P}<0.01)$.

Table-II

Effect of Captopril on blood urea nitrogen (BUN) in Gentamicin induced nephrotoxic rats in experiment II.

\begin{tabular}{lcc}
\hline Group of rats & No of rat (n) & $\begin{array}{c}\text { Blood urea } \\
\text { nitrogen (BUN) } \\
\text { (Mean } \pm \text { SEM) }\end{array}$ \\
\hline CControl & 7 & $117.00 \pm 0.81$ \\
DExperimental & 7 & $85.28 \pm 1.14^{*}$ \\
EExperimental & 7 & $75.00 \pm 0.81^{*}$ \\
\hline
\end{tabular}

C Vs D $\quad-\quad P<0.01$

C Vs E - $\quad \mathrm{P}<0.05$

Effect of Captopril on proximal convoluted tubules in Gentamicin induced nephrotoxic rats in experiment-II: 
The mean number of necrosed proximal convoluted tubules of rats in group $\mathrm{C}$ was $12.71 \pm 0.28$ and group D was $12.28 \pm 0.35$ and group $\mathrm{E}$ was $11.57 \pm 0.29$ respectively. The mean number of necrosed proximal convoluted tubules of rats in group D was not decreased in comparison to $\mathrm{C}$ which is not significant $(P>0.05)$. The mean number of necrosed proximal convoluted tubules of rats in group $\mathrm{E}$ was decreased in comparison to group $\mathrm{C}$ which is significant $(\mathrm{P}<0.01)$.

Table-III

Effect of Captopril on proximal convoluted tubules in Gentamicin induced rats in experiment II.

\begin{tabular}{lcc}
\hline Group of rats & $\begin{array}{c}\text { No of } \\
\text { rat (n) }\end{array}$ & $\begin{array}{c}\text { Number of } \\
\text { necrosed } \\
\text { convoluted tubules } \\
(\mathrm{HPF})(\text { Mean } \pm \text { SEM) }\end{array}$ \\
\hline CControl & 7 & $12.71 \pm 0.28$ \\
DExperimental & 7 & $12.28 \pm 0.35^{\text {ns }}$ \\
EExperimental & 7 & $11.57 \pm 0.29^{*}$ \\
\hline
\end{tabular}

C Vs D - $\quad P>0.05$

$\mathrm{CVsE} \quad-\quad \mathrm{P}<0.01$

\section{Discussion:}

The present study was carried out to evaluate the effect of Captopril on gentamicin-induced nephrotoxicity in rats. 35 Long Evens rats were included in the study.

In the present study, the nephrotoxicity was induced in rats by administration of gentamicin at a dose of $125 \mathrm{mg} / \mathrm{kg}$ body weight with gentamicin for 9 days. The dose of gentamicin was determined on the basis of reports of Falco et al. ${ }^{14}$. The nephrotoxicity was evidenced by a significant increase in serum creatinine, blood urea nitrogen (BUN) and histologically necrosed areas in proximal convoluted tubules.

In the present study the necrosed proximal convoluted tubules were counted per highpower field of microscope and showed significant damage in Group-B and group-C. Captopril in this study, showed some protective effect against gentamicin-induced nephrotoxicity. This was revealed by significant weight gain and reduced value of blood urea nitrogen (BUN) levels in rats when treated with both captopril and gentamicin.

It has been reported that captopril retards the progression of renal damage ${ }^{15}$, as one of the sequence of events leading to nephrotoxicity is failure of glomerular filtration due to decreased renal perfusion pressure or persistent preglomerular vasoconstriction, possibly related to the activity of the renin angiotensin system.

The effects of captopril may be mediated through the interruption of rennin asgiotensin system (RAS) influence of efferent arteriolar resistance and mesangial cell contractility. Other possible mechanisms for the action of angiotensin converting enzyme inhibitors which deserve consideration include impairment of the degradation of vasodilator kinis and increased production of vasodilator prostaglandin ${ }^{16}$. The mechanism by which captopril and other converting enzyme inhibitors mitigate the progression of glomerular injury warrants further investigation their potential effect of the RAS may enhance the understanding of progressive renal disease.

This study provides an initial step to demonstrate the protective effect of captopril in gentamicin induced nephrotoxicity in rats. Thus it could be a new agent in reducing morbidity and mortality resulting from nephrotoxicity. However, the promising nephroprotective effect of captopril should be weighed along with its easy availability. The findings presented here provide a baseline for future studies designed to quantify the effects of captopril in gentamicin induced nephrotoxicity in rats.

\section{References:}

1. Chambers HF. The amino glycosides. IN: HardmanJ G, Limbird LE. (ed), Goodman and Gilman's the Pharmcological basis of therapeutics. 10th ed. Newyork; Mc Graw-Hill Book Company Inc; 2001: p. 1219-31.

2. Hamilton DV. Evans B. Maidment G. Pryor JJ. Captopril for refractory hypertension in patient with chronic renal failure and renal transplantation. J R Soc Med. 1981; 74; 357-362. 
3. Kosek JC, Mazze RI, Cousins MJ, Nephrotoxicity of Gertamicin. Lab Invest. 1974; 30: 48-57.

4. Mathew TH. Drug-Induced renal disease. Med J Aust. 1992; 156: 724-28.

5. Begum NA. Study of the effect of Nigella stivalinn (kalajira) extract on gentamicin-induced nephrotosicity in rats. [M.Phil. thesis]. Dhaka: BSMMU; 2006.

6. Smith CR, Baughman KL, Edwards CQ, Rogers JF, Leitman PS. Controlled comparison of amikacin and gentamicin. N Engl J Med. 197; 296: 349-53.

7. Wilfert JN, Burke JP. Bloomer HA, Smith CB. Reanl insufficiency associated with gentamicin therapy. J Inf. Dis 1971; 124: 148-53.

8. Schultze RG, Winters RE, Kauffman H. Possible nephrotoxicity of gentamicin. J Infect Dis. 1971; 124 (Suppl): 145-47.

9. Walker PD. Shah SV, Evidence suggesting a role for hydroxyl radical in gentamicin induced acute renal failure $\mathrm{n}$ rats. J Clin Invest. 1988; 81: 33441 .

10. Lopez-overjero JA, Sall SD, D. Angelo WA. Cheigh JS, Stenzel KH, Laragh JH. Reversal of malignant hypertension and scleroderma renal vascular crisis by angiotensin converting enzyme inhibitor captopril. N Engl J Med. 1979; 300: 1417-9.

11. Zawda JR, Clements PJ, Furst DA, Bloomer A, Paulus HE, Maxwell MA. Clinical course of patient with scleroderma renal crisis treated with captopril. Nephron. 1981; 27: 74-8.

12. Whitman HH, Case DB, Laragh JH. Variable response to oral angiotensin- converting enzyme blockade in hypertensive scleroderma patients. Arthritis Rheum. 1982; 25: 74-8.

13. Sorenson LB, Paunicka K, Harris M. Reversal of scleroderna renal crisis for more than 2 year in patient treated with captopril. Arthritis Rheum. 1983; 26: 797-800.

14. Falco FG, Smith HM, Arcieri GM. Nephrotoxicity of aminoglycosides and gentamicin. J Infect Dis. 1969; 119: 406-9.

15. Hall RL. Wilke WL. Fettman MJ. Captopril slows the progression of chronic renal disease in partially nephrectomized rats. Toxicol Appl Pharmacol. 1985; 80(3): 517-26.

16. Gotoh S; Ogihara T, Nakamaru. M; Higaki. J, Ohde, H, Tabuchi. Y, Kumahara, Y, And Nish-INo T. Effect of captopril on renal vascular resistance renin prostaglandin and kinin in the isolated perfuse kidney. Life Sci. 1983; 33: 2409-13. 